(C) Likhachov V.K., Shymanska Ya.V., Dobrovolska L.M.

UDC 612.017+612.8]-06:[618.177-089.888.11+618.396]

DOI https://doi.org/10.31718/mep.2021.25.1-2.03

\title{
THE RELATIONSHIP BETWEEN CHANGES IN IMMUNE STATUS AND DISORDERS OF PSYCHO-EMOTIONAL STATE IN PREGNANT WOMEN WITH IN VITRO FERTILIZATION AND THREATENED PREMATURE BIRTH*
}

\author{
Likhachov V.K., Shymanska Ya.V., Dobrovolska L.M.
}

Ukrainian Medical Stomatological Academy

The topic of the research and development project of the Department of Obstetrics and Gynecology No.2, Ukrainian Medical Stomatological Academy: "The role of chronic infection of the uterus and lower genital tract in the formation of obstetric and gynecological pathology" (state registration No. 0117U005276, performance period 2017-2022).

У жінок, які переживають невдачі на етапі запліднення чи при виношуванні вагітності, врезультаті тривалих негативних емоцій може розвинуться психо-емоційний стрес із високим рівнем тривожності, невротичним конфліктом, що часто супроводжується ускладненим перебігом вагітності. В світовій літературі обговорюється можливий зв'язок між високим рівнем тривожності і депресією, з одного боку, та змінами стану імунної системи, з іншого боку. Метою дослідження стало виявлення взаємозв'язку між психо-емоційними зрушеннями у вагітних з екстракорпоральним заплідненням і загрозою передчасних пологів та змінами імунного статусу у них. Вивчався психоемоційний стан у 60 жінок в другому триместрі вагітності з непліддям в анамнезі, вагітність у яких наступила в результаті ЕКЗ, та із загрозою передчасних пологів. В якості контролю були обстежені 20 здорових жінок з фізіологічним перебігом вагітності. Оцінювали рівні особистісної(ОТ) та ситуативної тривожності (СТ) $і$ ступіньдепресивних розладів у таких жінок. Паралельновизначали рівні про- та протизапальних цитокінів, стан клітинно-гуморального імунітету і шукали кореляційні зв'язки між цими показниками і рівнями тривожності та проявами депресії у обстежених пацієнток. У вагітних жінок з екстракорпоральним заплідненням та загрозою передчасних пологів виявлені: високий рівень ситуативної (у 53,3\% жінок) та особистісної (у 56,8\% жінок) тривожності; у 70\% вагітних домінують ейфоричний, тривожний та депресивний типи психологічного компоненту гестаційноїдомінанти; у 33,3\% обстежених жінок знайдений стан легкої та замаскованої депресії. Виявлені кореляційні звязки між збільшенням балів CT і OTта зростанням концентрації TNF-a і INF-V, а також між зростанням рівня TNFa і бальним показником вираженності депресії. Знайдений звязок між зниженням кількості Т-хелперів та зростанням бальної оцінки ОТ у них.

Ключові слова: екстракорпоральнезапліднення, загроза передчасних пологів, тривожні розлади, цитокіни, Т-хелпери

Women who experience failures at the stage of fertilization or during pregnancy can develop psycho-emotional stress as a result of prolonged negative emotions with a high level of anxiety, neurotic conflict, often accompanied by a complicated pregnancy. The international academic literature discusses a possible link between high levels of anxiety and depression, on the one hand, and changes in the state of the immune system, on the other. The aim of the research was to identify the relationship between psycho-emotional changes in pregnant women with in vitro fertilization and threatened premature birth and changes in their immune status. The psycho-emotional state was studied in 60 women in the second trimester of pregnancy with a history of infertility, whose pregnancy resulted from IVF, and with threatened premature birth. As a control group, 20 healthy women with a physiological course of pregnancy were examined. The levels of trait (TA) and state anxiety (SA), as well as the degree of depressive disorders in these women, were assessed. In parallel, the levels of pro- and anti-inflammatory cytokines and the state of cellular-humoral immunity were determined, looking for correlations between these indicators, the levels of anxiety, and manifestations of depression in the examined patients. Pregnant women with in vitro fertilization and threatened premature birth revealed high levels of state (53.3\% of women) and trait (56.8\% of women) anxiety; $70 \%$ of pregnant women are dominated by euphoric, anxious, and depressive types of the psychological component of gestational dominant; $33.3 \%$ of the examined women demonstrated a state of mild and masked depression. Correlations were found between an increase in SA and TA scores and an elevated concentration of TNF- $a$ and INF- $y$, as well as between an increase in the level of TNF- $a$ and the score of depression. $A$ connection was found between a decrease in the number of T-helpers and an increase in the TA score in the examined patients.

Key words: in vitro fertilization, threatened premature birth, anxiety disorders, cytokines, T-helpers.

During pregnancy, the body of a healthy woman undergoes psychological changes that contribute to the successful carrying and prepare it for future childbirth and motherhood $[1,6,10]$. In women who experience failures at the stage of fertilization or during pregnancy (not asso- ciated with a hereditary predisposition to miscarriage [21]) can develop psycho-emotional stress as a result of prolonged negative emotions $[6,12]$.

The medium level of anxiety is considered by most authors as normal (adaptive) during pregnancy, while

${ }^{*}$ To cite this English version: Likhachov V.K., Shymanska Ya.V., Dobrovolska L.M. The relationship between changes in immune status and disorders of psycho-emotional state in pregnant women with in vitro fertilization and threatened premature birth . // The Medical and ecological problems. - 2021. - Vol 25, № 1-2. - P. 12-16. 
high levels of anxiety are often accompanied by a complicated course of pregnancy $[1,3,8,12]$.

The high level of trait anxiety (TA) indicates that the examined women are more prone to the effects of stress and anxiety, they associate negative events only with their personality. TA directly correlates with the presence of neurotic conflict and psychosomatic diseases [1,12].

State anxiety (SA) indicates emotional discomfort in women at the time of the study, associated with the expectation of trouble, it is characterized by tension, anxiety, and causes attention disorders $[13,19]$.

Women with a high level of anxiety should not be given categorical tasks and should not be encouraged to quickly perform certain actions, as this can cause conflict or nervous excitement in a pregnant woman $[1,12]$. The study of the psychological component of gestational dominant (PCGD) allows us to identify women with the euphoric, depressed, and anxious types of PCGD. A pregnant woman either overestimates the existing problems or cannot explain the cause of anxiety that she constantly experiences; anxiety is often accompanied by hypochondria $[12,13]$.

We decided to study the immune status of the examined women to reveal possible causes of high levels of anxiety and depression $[9,13,18,19]$. The aim of the study was to identify the relationship of the psycho-emotional changes in pregnant women with in vitro fertilization and threatened premature birth with the changes in their immune status.

\section{Materials and methods}

The psycho-emotional state was studied in 60 women in the second trimester of pregnancy with a history of infertility, whose pregnancy resulted from IVF, and with threatened premature birth (group I).

As a control group, 20 healthy women with a physiological course of pregnancy (group II) were examined. Quantitative expression of the influence of stress-inducing factors and their perception by pregnant women was assessed by the level of trait and state anxiety and the degree of depressive disorders, which were determined by questionnaires using the following methods $[11,20]$ :

- The Spielberger-Hanin scale to determine trait anxiety (TA) and state anxiety (SA);

- The "Pregnant woman's attitude test" by V.I. Dobryakov;

- methods of differential diagnosis of depressive states according to Zung.

The Spielberger-Hanin scale consists of individual statements that allow us to assess state anxiety (level of anxiety at the moment) and trait anxiety (anxiety as a stable characteristic of a personality). SA is characterized by tension, anxiety, nervousness, TA directly correlates with the presence of neurotic conflict, emotional breakdowns, and psychosomatic diseases $[1,13,19]$.

The result of this test is evaluated as follows: 30 points - low anxiety; 31-45 points - moderate anxiety; 46 or more points $-a$ high level of anxiety.

The "Pregnant woman's attitude test" by V.I. Dobryakov helps to determine the psychological component of gestational dominant (PCGD), which is a set of mechanisms of mental self-regulation, activated during pregnancy and aimed at forming behavioral stereotypes in pregnant women for maintaining pregnancy and creating conditions for child's development $[1,12]$.

The Zung questionnaire is designed and adapted for examination of pregnant women in order to diagnose depres- sive states. An indicator of the level of depression (LD) not more than 50 points is a state without depression; LD in the range of 50-59 points indicates a mild degree of depression; LD from 60 to 69 points - a subdepressive state or masked depression; LD more than 69 points - a depressed state. Initial testing of women in group I was carried out at a hospital, at the beginning of hospitalization, in the presence of threatened premature birth.

Healthy pregnant women in group II (control) were tested at a women's consultation clinic. Simultaneously with the study of the psycho-emotional state in pregnant women with IVF and threatened premature birth, we determined the levels of pro- and anti-inflammatory cytokines, as well as the state of cellular and humoral immunity in these patients [22], looking for correlations between these indicators and levels of anxiety and depression. The concentrations of cytokines TNF- $\alpha$, INF- $\gamma$, and IL-10 were determined by enzyme-linked immunosorbent assay using appropriate standard commercial reagent kits from Vector BEST according to the manufacturer's instructions. Commercial erythrocyte diagnosticums of antibodies of classes CD3+, CD4+, CD8+, CD22+ LLC Research and Production Laboratory "Granum" (Ukraine, Kharkiv) were used to study the indicators of cellular immunity.

Determination of serum immunoglobulin concentration was performed using a test system for analysis of $A$, $M, G$ immunoglobulins in blood serum using competitive enzyme-linked immunosorbent assay $[5,7,15,16,17]$.

\section{Results and discussion}

A high level of state anxiety was registered in 32 pregnant women $(53.3 \%)$ of group I with a score of $47.4 \pm 0.5$ points, whereas in group II no woman had a high level of SA. A medium level of SA was found in 22 women (36.7\%) of group I with a rate of $38.9 \pm 0.8$ points and in the vast majority of women in the control group (85\%) with a rate of 35.9 \pm 0.9 points. A low level of SA was found in $10 \%$ of women in group I ( $28.3 \pm 1.3$ points) and in $15 \%$ of pregnant women in group II ( $25.0 \pm 1.2$ points).

High trait anxiety was detected in $56.8 \%$ of the examined pregnant women in group I and amounted to $48.4 \pm 0.6$ points, whereas in the control group a high level of TA was detected only in 1 woman (5\%) and amounted to 47 points. A medium level of trait anxiety was found in $31.7 \%$ of pregnant women in group I and in the vast majority of pregnant women in the control group (90\%); besides, the average score of TA was higher in group I (39.0 \pm 1.0 points against $35.7 \pm 0.7$ points in group II; $p<0.002$ ). A low level of TA was observed in $11.7 \%$ of women in group I and in $5.0 \%$ of pregnant women in the control group.

According to studies of the psychological component of gestational dominant (PCGD) among the examined pregnant women of group I, the anxious type prevailed in 20 women $(33.3 \%)$, the euphoric type - in 15 women $(25 \%)$, and the depressive type - in 7 women $(11.7 \%)$. That is, an inadequate psychological component of gestational dominant, which was found in $70 \%$ of pregnant women with IVF and threatened premature birth negatively affects their somatic status $[11,13]$. Such pregnant women overestimate the existing problems, and any actions of medical staff (laboratory examination, doctor's examination) increase their anxiety $[1,6,12]$.

The control group (healthy pregnant women) is dominated by the optimal type of gestational dominant in 18 women $(90 \%)$, which indicates the correct attitude of these women to their pregnancies - responsibly, but without much anxiety. Such pregnant women continue to 
lead an active lifestyle, follow the doctors' recommendations, and monitor their health [12].

When assessing depressive states according to the Zung questionnaire, it was found that $66.7 \%$ of women with IVF and threatened premature birth (40 subjects) had no depression, whereas $30 \%$ (18 women) demonstrated mild depression, and two pregnant women (3.3\%) were diagnosed with masked depression. In the control group, all women were without depression. The state of mild and masked depression, found in 20 women of group I (33.3\%), can be explained by a history of infertility, fear of failure in this pregnancy, developed complex of physical and / or psychic inferiority $[1,12]$. That is, pregnant women with in vitro fertilization and threatened premature birth have the following changes in the psycho-emotional sphere:

- high level of state (53.3\% of women) and trait (56.8\% of women) anxiety;

- $70 \%$ of pregnant women are dominated by euphoric, anxious, and depressive types of the psychological component of gestational dominant;

- the state of mild and masked depression was found in $33.3 \%$ of examined women.

To find a link between psycho-emotional disorders in pregnant women and changes in the cellular and humoral immunity, we determined the concentrations of pro- and anti-inflammatory cytokines in the blood of these patients, assessed the state of cellular and humoral immunity, and calculated the correlations between these indicators and the levels of anxiety and manifestations of depression.

In pregnant women of group I (with IVF and threatened premature birth), we found an increase in the concentration of pro-inflammatory cytokines in patients with high levels of anxiety and depression. Thus, the INF-y index increased by 1.5 times (from $5.81 \pm 0.21 \mathrm{pg} / \mathrm{ml}$ to $8.66 \pm 0.50 \mathrm{pg} / \mathrm{ml} ; \mathrm{P} 1<0.001)$, and the TNF- $\alpha$ index - by 2.3 times (from $2.80 \pm 0.15 \mathrm{pg} / \mathrm{ml}$ to $6.44 \pm 0.38 \mathrm{pg} / \mathrm{ml}$; $\left.\mathrm{P}_{1}<0.001\right)$. The level of anti-inflammatory cytokine IL-10 decreased by 1.9 times (from $9.52 \pm 0.47 \mathrm{pg} / \mathrm{ml}$ to $\left.5.04 \pm 0.36 \mathrm{pg} / \mathrm{ml} ; \mathrm{P}_{1}<0.001\right)$. In these women, a significant correlation was found between the number of points in terms of state anxiety and the concentration of TNF- $\alpha$ $\left(r=0.71 ; P_{1}<0.01\right)$ and the number of points in terms of trait anxiety and the level of INF-Y $\left(r=0.67 ; P_{1}<0.02\right)$.

There was a negative correlation between an increase in trait anxiety and a decrease in the concentration of the anti-inflammatory cytokine IL-10 ( $r=-0.59$; $\left.\mathrm{P}_{1}<0.05\right)$. When comparing the concentration of proinflammatory cytokines and scores on the level of depression according to Zung, a significant correlation was found between the increase in the concentration of TNF$\alpha$ and scores indicating the presence of mild and masked depression $\left(r=0.63 ; P_{1}<0.05\right)$.

In the group of pregnant women with IVF, threatened premature birth and high levels of anxiety and depression, we found a decrease in the concentration of CDC+ $T$ cells due to a decrease in the content of T-helpers (CD4+) (from $0.60 \pm 0.04$ per $10^{9} / \mathrm{I}$ in healthy pregnant women up to $0.43 \pm 0.03$ per $10^{9} / \mathrm{I}$ in patients; $\left.\mathrm{P}_{1}<0.002\right)$ and T-suppressors / killers (CD8+) (from $0.38 \pm 0.03$ per $10^{9} /$ I to $\left.0.30 \pm 0.0210^{9} / \mathrm{I} ; \mathrm{P}_{1}<0.05\right)$. The concentration of $B$ cells $(C D 22+)$ decreased from $0.66 \pm 0.04$ per $10^{9} /$ I in healthy pregnant women to $0.42 \pm 0.03$ per $10^{9} / \mathrm{I}$ in pregnant women with high levels of anxiety and depression $\left(P_{1}<0.001\right)$. A negative correlation was calculated between a decrease in the number of T-helpers in the blood of women in group I and an increase in the score of trait anxiety in these patients $\left(r=-0.70 ; P_{1}<0.01\right)$.

Furthermore, in pregnant women with depression, a negative association was found between a decrease in the content of T-helpers and an increase in the level of pro-inflammatory cytokine TNF- $\alpha$ in the blood $(r=-0.59$; $\left.\mathrm{P}_{1}<0.05\right)$. These results coincide with the data given in the study by Mayorova MA et al., 2020 [9].

In pregnant women with IVF and the risk of premature birth, who developed anxiety and depression, we found a decrease in $\lg A$ (from $2.10 \pm 0.12 \mathrm{~g} / \mathrm{I}$ in healthy pregnant women to $1.48 \pm 0.07 \mathrm{~g} / \mathrm{I}$ in patients; $P_{1}<0.001$ ) and IgG levels (from $14.06 \pm 0.4 \mathrm{~g} / \mathrm{I}$ in healthy pregnant women to $10.3 \pm 0.7 \mathrm{~g} / \mathrm{I}$ in patients; $\left.P_{1}<0.001\right)$, which coincides with the data given by Haustova O.O., 2017 [13]. At the same time, the detected increase in IgM concentration (from $1.50 \pm 0.07 \mathrm{~g} / \mathrm{I}$ in healthy pregnant women to $2.09 \pm 0.11 \mathrm{~g} / \mathrm{I}$ in patients; $\mathrm{P}_{1}<0.001$ ) corresponds to the reports by Fatemeh Hoseinzadeh et al., 2016 and Irwin M., Miller F., $2007[18,19]$.

A negative correlation between an increase in the score of trait anxiety and $s$ decrease in IgA concentration in the examined women $\left(r=-0.68 ; P_{1}<0.01\right)$ indicates the presence of chronic stress in pregnant women with IVF and the risk of premature birth [7.9].

Based on the results of the study, we believe it is possible to propose the following outline on the occurrence of increased levels of anxiety and depression in the examined women:

- human mood is an integral consequence of genetically and epigenetically determined activity of the neuroimmune-endocrine interface and is determined by the metabolic performance of the nervous, immune, and endocrine systems [3,6,9,12];

- risk factors for depression include cytokine imbalance (predominance of pro-inflammatory cytokines INF- $\gamma$ and TNF- $\alpha$ over anti-inflammatory cytokines IL-10, etc.), since pro-inflammatory signaling, affecting astrocytes and brain microglia, reduces dopamine, norepinephrine and serotonin levels and thus causes cognitive impairment [9];

- it was also found [2] that pro-inflammatory cytokines INF-y and TNF- $\alpha$ significantly affect the hypothalamicpituitary-adrenal axis, increasing the systemic level of cortisol, which contributes to the development of affective and cognitive disorders; we also found significant positive correlations between the increase in TNF- $\alpha$ concentration and the number of points for state anxiety and between the increase in TNF- $\alpha$ levels and the depth of depression score according to Zung;

- according to the literature $[14,17]$ and based on the results of our studies (negative correlation between a decrease in the number of T-helpers in women with IVF, the risk of premature birth and depression, as well as an increase in the score of trait anxiety in these patients), it can be argued that deficiency of T-regulatory cells (CD4+) may play a protective role in the occurrence and progression of anxiety and depression in pregnant women with IVF and threatened premature birth.

Thus, it is likely that the revealed deviations in the parameters of the immune system (imbalance of pro- and anti-inflammatory cytokines in favor of pro-inflammatory fractions, as well as T-helper deficiency) in pregnant women with IVF and threatened premature birth contribute to the disorders of their psycho-emotional state with a high level of state and trait anxiety, the dominance of euphoric, anxious, and depressive types of the psycho- 
logical component of gestational dominant and the state of mild and masked depression.

\section{Conclusions}

The women with in vitro fertilization and threatened premature birth revealed the following:

1) a high level of state (53.3\% of women) and trait ( $56.8 \%$ of women) anxiety; $70 \%$ of pregnant women were dominated by euphoric, anxious, and depressive types of the psychological component of gestational dominant; mild and masked depression was found in $33.3 \%$ of the examined women.

2 ) increased concentrations of pro-inflammatory cytokines INF-Y (by 1.5 times) and TNF-a (by 2.3 times), whereas the level of anti-inflammatory cytokine IL-10 decreased by 1.9 times;

3) significant positive correlations between the number of state anxiety scores and TNF- $\alpha$ concentration, the number of trait anxiety scores, and the level of INF- $y$, as well as between the increase in the concentration of proinflammatory cytokine TNF- $\alpha$ and Zung depression score.

A negative correlation was found between an increase in trait anxiety and a decrease in the concentration of the anti-inflammatory cytokine IL-10;

4) a negative correlation between a decrease in the number of T-helpers in women with IVF, the risk of premature birth and depression, and an increase in the score of trait anxiety in the examined patients; a negative relationship was found between a decrease in the content of T-helpers in the blood and an increase in the level of the pro-inflammatory cytokine TNF- $\alpha$;

5) a negative correlation between an increase in the score of trait anxiety and a decrease in the concentration of IgA in the examined women. The direction of further research is the development and testing of preventive treatment for pregnant women with IVF and a high risk of premature birth, taking into account the possibility of medication correction of psycho-emotional disorders in these patients.

\section{References}

1. Baranova VV. Osoblyvosti psyxoemocijnoho stanu žinok, jaki majut' reproduktyvni vtraty $v$ anamnezi $v$ umovax teperišn'oji vahitnosti.[Psychoemotional peculiarities of women who have a history of miscarriage and a loss during the current pregnancy]. Perynatolohyja y pedyatryja. 2017; 1(69),70-73.

2. Venckivs'kyj BM, Poladyč IV, Avramenko SO. Rol' prozapal'nyx cytokiniv u patohenezi peredčasnoji polohovoji dijal'nosti pry bahatoplidnij vahitnosti, jaka nastala vnaslidok zastosuvannja dopomižnyx reproduktyvnyx texnolohij. [The role of inflammatory cytokinesin the pathogenesis of premature labor in multiple pregnancy as a result of ART]. Zdorov'ye zhenshchiny. 2016; 5(111), 73-76.

3. Vorobiova II, Skripchenko NYa, Tkachenko VB, Zhivets'kaDenisova AA. Rol' molekulyarno-henetychnykh ta psykhosotsial'nykh aspektiv rozvytku nevynoshuvannya vahitnosti u zhinok ukrayins'koyi natsiyi. The role of molecular-genetic and psycho-social aspects of the development of miscarriage in women of the Ukrainian nation]. Akusherstvo.2018;15: 31-37.

4. Dobrokhotova YuE, Gankovskaya LV, Bakhareva IV, Svitich OA, Malushenko SV, Magomedova AM. Rol' immunnykh mekhanizmov $v$ patogeneze nevynashivaniya beremennosti. The role of immune mechanisms in the pathogenesis of miscarriage]. Mezhdunarodnyy meditsinskiy zhurnal.2012; 18(3):48-50.

5. Dons'koy BV. Imunni faktory u reproduktsiyi: prohnozuvannya uspishnosti reproduktyvnoho protsesu.[Immune factors in reproductions. Immune accentuations theory and prognosis of reproductive success]. Medytsynskye aspekty zdorov'ya zhenshchyny.2014; 4(79): 53-59.

6. Zhuk SI, Shchurevs'ka OD. Psykhosotsial'ni aspekty zahrozy peredchasnykh polohiv. Threat of premature birth: psychosocial aspects]. Zdorov'e zhenshchyny. 2016;6(112):86-89.
7. Lytvyn NV. Imunolohichni vzayemodiyi orhanizmu zhinok iz bezplidnistyu, vklyuchenykh u prohramu IVF. [Immunological interaction of organisms of the women with infertility included in the IVF program]. Zdorov'e zhenshchyny. 2017;6(122):132139.

8. Maydan IS. Pislyapolohova depresiya u porodil'. Ohlyad suchasnykh danykh.[ Postpartum depression in women in labor. Overview of current data]. Slovo o zdorov'e.2017; 4(10):34-36.

9. Mayorova MA, Petrova NN, Stroyev YUI, Churilov LP, Shenfel'd I. Vzaimosvyaz' autoimmunnykh protsessov, endokrinnykh narusheniy i depressii. [Interrelation of auto-immune process, endocrine disorders and depression]. Obozreniye psikhiatrii i meditsinskoy psikhologii. 2020; 1: 8-19.

10. Mandrykova AS. Optymizatsiya taktyky vedennya vahitnosti ta rannikh peredchasnykh polohiv u zhinok pislya zastosuvannya dopomizhnykh reproduktyvnykh tekhnolohiy. [Optimization of tactics of pregnancy and early premature birth in women after the use of assisted reproductive technologies]. Zdorov'e zhenshchyny. 2018; 5(131):104-107.

11. Pushkar'ova TM, Skrypchenko NYA. Alhorytm skryninhovoyi diahnostyky depresyvnykh i tryvozhno-depresyvnykh rozladiv $\mathrm{u}$ zhinok pid chas vahitnosti ta pislya polohiv. [Screening diagnostic algorithm of anxiety and anxiodepressive disorders in women during pregnancy and postpartum period]. Perynatolohyya y pedyatryya. $2017 ; 1$ (69):74-78.

12. Syusyuka V. Psykhoemotsiynyy stan zhinok pid chas fiziolohichnoho ta patolohichnoho perebihu vahitnosti. [Psychoemotional state of women during the physiological and pathological course of pregnancy]. Z turbotoyu pro zhinku. 2018;6(90). Available from: https://extempore.info/component /content/article/9-joornal/1530-psykhoemotsiynyy-stan-zhinokpid-chas-fiziolohichnoho-ta-patolohichnoho-perebihuvahitnosti.html? ltemid=357

13. Khaustova OO. Neyroimunoendokrynolohiya: suchasnyy pohlyad na psykhosomatychnyy dialoh lyudyny zi stresom. [Neuroimmunoendocrinology: a modern look at the psychosomatic dialogue of a person with stress]. Liky Ukrayiny. 2017; 1(207):16-23.

14. Alijotas-Reig J, Llurba E, Gris JM. Potentiating maternal immune tolerance in pregnancy: a new challenging role for regulatory T cells. Placenta. [Internet]. 2014; 35:241-248. Available from: https://doi.org/10.1016/j.placenta.2014.02.004

15. Chatterjee $\mathrm{P}$, Chiasson VL, Bounds KR, Mitchell BM. Regulation of the anti-inflammatory cytokines interleukin- 4 and interleukin-10 during pregnancy. Front. Immunology.2014;27(5):253. Available from: https://doi.org/10.3389/fimmu.2014.00253

16. Cheng SB, Sharma S. Interleukin-10: a pleiotropic regulator in pregnancy. American Journal of Reproductive Immunology. 2015;73: 487-500. Available from: https://doi.org/10.1111/aji.12329

17. Gomez-Lopez N, StLouis D, Lehr MA, et al. Immune cells in term and preterm labor. Cellular and molecular immunology. 2014;11(6):571-581. Available from: https://doi.org/10.1038/cmi.2014.46

18. Hoseinzadeh F, Abadi PH, Agheltar M, Aghayinejad A, Torabian F, Rezayat A et al. The Role of Immune System in Depression Disorder. Health. 2016; Vol.8 No 15: 1726-1743. Available from: http://dx.doi.org/10.4236/health.2016.815167 doi: 10.4236/health.2016.815167.

19. Irwin MR, Miller AH. Depressive disorders and immunity: 20 years of progress and discovery. Elsevier Inc. All rights reserved. 2007:21:374-383.

20. Rollo M, Zavalova MI, Siburina AU, redaktory. Smysl trevogi. [Meaning of anxiety]. Moskva. Klass 2001. 258s.

21. Rudenko IV, Lihachov VK, Mischenko VP, Golubenko MY, Shymanska YV. Medico-genetic diagnosis of hereditary predisposition to noncfrrying of pregnancy and reproductive. Svit medicine I biologiyi. 2018.2(64):75-77.

22. Yuan JLi J, Huang SY, Sun X. Characterization of the subsets of human NK T-like cells and the expression of Th1/Th2 cytokines in patients with unexplained recurrent spontaneous abortion. J. Reproductive immunology. 2015;110: 81-88. : https://doi.org/10.1016/j.jri.2015.05.001

Матеріал надійшов до редакції 04.03.2021 